\title{
XXI. On animal cotton, and the insect which produces it
}

\section{Baudry des Lozieres}

To cite this article: M. Baudry des Lozieres (1804) XXI. On animal cotton, and the insect which produces it , Philosophical Magazine Series 1, 19:74, 120-122, DOI: 10.1080/14786440408676536

To link to this article: http://dx.doi.org/10.1080/14786440408676536

曲 Published online: 18 May 2009.

Submit your article to this journal

Џ Article views: 2

Q View related articles $\asymp$ 
arising from the red salt; for the new solution which thence results is still precipitated red, though less intense : so that, if these operations were repeated several times on the same piatina, it would at length be freed from this foreign metal. The authors found also anuther method of separating this metal from platina: it consists in dissolving the red salt in boiling water, and mixing with it, as soon as it is dissolved, caustic potash. The liquor then becomes turbid, and there are formed in it green flakes, which when wastred and heated give the metal again. The-pale yellow precipitate of platina, treated in the same manner, presented nothing of the same kind.

It is then proved by their experiments, that there exists in crude platina a new metal which communicates to the triple salts of platina the red colour which is almost always peculiar to them. As this metal is little susceptible of alteration by the agents employed to purify platina on a large scale, the authors suspected that traces of it more or less abundant ought still to be found in it; and this suspicion was confirmed by experience.

They found it in platina purified by C. Jannety and Necker Saussure in almost as great quantity as in crude platina; which induced them to say that in all probability they had not yet met with this metal in a state perfectly pure.

C. Vauquelin and Fourcroy terminate their niemoir by recapitulating briefly the different results to which they were conducted, and by saying that they suspect that the new metal cxisting in platina enters conjointly with the latter into the composition of the palladium announced by Mr. Chenevix.

They promise to continue their labour, and to procure a greater quantity of the new metal for the purpose of subjecting it to new experiments, that they may make themselves better acquainted with its properties, and particularly to discover means more proper for purifying platina than those hitherto known.

XXI. On Animal Cotton, and the Insect which produces it. By $M$. Baudry des Lozieres.

Some successful experiments have been made in America and the West Indies to preserve and increase the insect known there by the name of $f y$-carrier, which produces an 
animal cotton in many respects superior to vegetable cotton. An intcligent inember of the American Philosophical Socicty, M. Baudry des Lozieres, has drawn up an interesting memoir on this cotton, and the insect which produces it.

"Every inhabitant of the West Indies," says this gentheman, "knows and dreads the greedy worm which devours their indigo and cassada plantations; it is called bv some the cassarla worm; by others, the fly-carrier; and is produced, like the silk-worm, from eggs scattered by the mother after her metamorphosis into a whitish butterfly. The egg is hatched about the end of July, when the animal is decked with a robe of the most brilliant and variegated colours. In the month of August, when about to undergo its metamorphosis, it strips off its superb robe and puts on one of a beautiful sea green, which reflects all its various strades according to the different undulations of the animal, and the different accidents of light. This new decoration is the signal for its tortures. Immediately a swarm of ichneumon fites assail it, and drive their stings into the skin of their victim over the whole extent of its back and sides, at the same time slipping their eggs into the bottom of the wounds that they have made.

" Having performed this dreadful operation, the flies disappear, and the patient remains for an hour in a motionless state, out of which it awakens to feed with great voracity. Then his size daily increases till the time of his hatching of the ichneumon flies. The eggs deposited are hatched at the same moment, and the cassada is instantly covered with a thousand little worms. They issue out of him at every pore, and that animated robe covers him so entirely, that nothing can be perceived but the top of his head. As soon as the worms are hatched, and without quitting the spot where the eggs are which they have broken through, they vicld a liquid gum, which, by coning into contact with the air, is renclered slimy and solid. Each of these animalcula works himself a small coccon, in the shape of an cgg, in which he wraps himself, thus making, as it were, his own winding-sheet. They seem to be born but to die. These millions of cocoons, all close to each other, and the formation of which has not taken two hours, form a white robe, and in this the cassada worm appears elegantly clothed. While they are thus decking him, he remains in a state of almost lethargic torpidity:

"As soon as the covering is woven, and the little workmen, who have made it, have retired and hidden themselves in their cells, the worm endeavours to rid himself of his 
guests, and of the robe which contains them. He comes out of the inclosure deprived of all his former beauty, in a state of decrepitude, exhausted, and threatened with approaching death. He strortly passes to the state of a chrysalis; and, after giving life to thousands of eggs, suddenly loses his own, leaving to the cultivator an advantage which may be so improved, as to more than compensate the ravages which he occasions. In about eight days, the little worms contained in the cocoons are metamorphosed into flies, having four wings. Their antennæ are long and vibraling; some have a tail, others do not show it; they feed upon small insects of the family of acarus, and evidently belong to the ichneumon tribe.

"The cotton-shell or wrapper is of a dazzling white, and as soon as the flies have quitted the cocoon it may be used without any preparatory precaution; it is made up of the purest and finest cotion; there is no refuse, no inferior quality in it; every part is as fine and beautiful as can be imagined."

M. D. Lozieres, the author of this memoir, urges the Americans to preserve and endeavour to increase the flycarrier, in the same manner and for similar purposes that the breed of the silkworm is encouraged. He declares that he has frequently seen so abundant a harvest of the animal cotton, that in the space of two hours he could collect the qrantity of one hundred pints, French measure. Moreover, animal cotton is attended with none of the difficulties which occur in the preparation of vegetable cotton, and it requires less time and less trouble to procure it; and there seems to him no doult that it will stand the competition with silk and with vegetable cotton: these, when applied to wounds, serve only to inflame and envenom; but the animal cotton may be used as lint, without the smallest inconvenience.

XXII. Report made to the Class of the Physical and Mathematical Sciences, ly C. Ramond, of a Memoir of C. Daubuissow on the Basaltes of Saxony.

[Concluded from p. 66.]

The author, supported by this series of observations, proceeds to the considerations which they suggest, and which appear to him proper for establishing the aqueous origin of basaltes. Such is the object of the third chapter. The following chapter is destined to strengthen this first conclusion 